\title{
COLLABORATION OF FAMILIES AND TEACHERS AS A FACTOR OF ENCOURAGEMENT OF SOCIAL EDUCATION
}

\author{
Daiva Alifanoviene \\ Liuda Radzeviciene
}

\author{
Zydra Musvicienè
}

Siauliai University, Lithuania

\begin{abstract}
Article reveals peculiarities of collaboration between parents and teachers in the education environment and development of collaboration opportunities. Successive impure strategy of research combining quantitative and qualitative methods is presented. Opinion on collaboration attributes of family members and school teachers $(N=176)$ is analyzed according to the semi structured interview data and applying method of Content analysis. Results of quantitative research that was done using questionnaire reveal peculiarities of collaboration in the process of social education highlighting successful and non-successful areas of collaboration discussed as well.
\end{abstract}

Keywords: collaboration, participants of education process, social nurture.

\section{Introduction}

Dictionary of modern Lithuanian language (2006) collaboration describe as common activity, acting together, focusing intellectual strength, trying to help to each other, coalescing for main goals. Scientific community acknowledges that it is rather difficult to find common, universal definition and model of collaboration that could fit to different areas of human wellbeing. And it is not an exception for practice of educational institutions.

Modern society that experience global challenges in pupil's social education is full of beneficiate unexpected events and stresses. Community of education institutions faces with complex social and educational problems that became great challenges for them. Pedagogues are responsible for children's welfare but without family and colleagues support, effective inter-collaboration with other institutions it is difficult to satisfy social wellness needs of all participants of educational process. Scientist's points that process of social education could be more effective when, on the one hand, pedagogues and other participants of education process are active, and on the other hand, when pedagogues professionally are able to manage process of social education both in institution and outside (Alifanovienè, Vaitkevičienè \& Musvicienè, 2014, Kontautienè, 2010, Merfeldaitė, 2009, Indrašienè, Kvieskienè \& Merfeldaitė, 2007).

Documents regulating education system of Republic of Lithuania indicate development, collaboration and constant reshaping attitudes between specialists 
and other societal groups concerning activities of education institutions (LR Švietimo ịstatymas, 2011, Valstybine švietimo strategija 2013-2022m.). In new documents that foreseen advancement in social and educational wellness of the country societal group of social exclusion, assailable stratum problems (especially neglecting of children's rights) are discussed, and the ways of solution of these problems are designed: bettering life quality, safeguarding equal rights and social welfare (Lietuvos pažangos strategijoje „Lietuva 2030“).

Child Welfare Program for 2013 - 2018 year points out necessity and satisfaction of pupil's needs and interests, creating for children conditions to be upbringing in the family, at the same time developing close relationships with institutions and specialists, to insure miscellaneous preventive, complex support and service accessibility in order to decrease social alliance and to create conditions for qualitative social education.

Purposeful and effective organization of the process of social education, collaboration of participant's of educational process is discussed in the documents regulating main activities of social educators of Lithuania as well: Social Educator Training Requirements (2001), Official Instructions of Social Educator (2001), and Regulation of Social Support Render (2011). Mentioned documents describe that seeking societal progress it is important to initiate changes in the main environments of person's development - family, educational system, community, public and cultural areas.

As Aramavičiūtè (2009), Leliūgienė \&Terechovienè, (2011), Vaitkevičiaus (1995) says in this context all participants of education process become important significantly: child and his/her family, school, community.

In this context the most important is perception of systemic- structural factors of social education that emphasize functions of participants of education process in different levels: involving collaboration and interrelations, which are the basis of integral system of social education (Aramavičiūte, 2009, Vaitkevičius, 1995, Bitinas, 2000).

How pedagogues and family members percept and assess attempts to collaborate and its importance in the whole education process? What forms of successful and unsuccessful collaboration they distinguish? These questions define the area of current research.

The aim of the research - is to analyze peculiarities of collaboration process in the school environment and to reveal successful and unsuccessful forms of collaboration.

Object of the research - peculiarities of collaboration of participants of educational process: opinion of pedagogues and parents.

Methodology and sample of the research To answer the questions of research successive impure strategy combining quantitative and qualitative approaches was chosen. 176 school pedagogues of different age and gender took part in the inquiry procedure. Closed type of questionnaire based on theoretical studies (Kontautienè, 2010; Merfeldaite, 2009; Vaitkevičius, 1995) and practical 
experience was designed. Applying designed questionnaire collaboration abilities and collaboration attempts of respondents were revealed. Using Likert's type rank scale respondents were asked to assess statements according to their intensity from exactly no up to exactly yes. Empiric data was processed applying SPSS17 program version, descriptive statistics methods (unitary and percentage frequency, mean rank, standard deviation) were used, as well as statistic analysis according to Student's $t$ criterion of $(t \leq 0,095)$. To evaluate inner reliability of the questionnaire Cronbach $\alpha$ indicator was used (indicator of inner consistency is $\alpha$ coefficient) on the supposition that it is sufficient when exceeding quantity of 0,75 .

Empiric data of qualitative research was gained applying semistructuralized interview of for 15 families in order to learn their opinion on peculiarities of collaboration.

Questions of interview were composed according to the scientific studies of authors mentioned above. Interview reveals opinion on significance of collaboration, attempts, successful and unsuccessful forms of collaboration. Empiric data of qualitative research was processed applying method of content analysis and validated by experts. Data of qualitative research was divided into diagnostic areas and categories.

\section{Analysis of collaboration peculiarities in the process of social education}

Statements educing pedagogue's collaboration abilities and attempts in order to make process of social education more qualitative, were given to respondents. Analyzing data concerning respondent's abilities and attempts for collaboration the indicator of inner reliability Cronbach $\alpha$ alfa $(\alpha=0,91)$ was set up, and this show high reliability of composed questionnaire (see Table 1).

Table 1. Analysis of Pedagogue's Ability of Collaboration

\begin{tabular}{|c|c|c|c|c|c|}
\hline Collaboration Ability & Gender & $\begin{array}{l}\text { Amount } \\
(\mathrm{N})\end{array}$ & $\begin{array}{l}\text { Mean } \\
\text { (M) }\end{array}$ & $\begin{array}{l}\text { Average } \\
\text { of } \\
\text { Standard } \\
\text { Deviation } \\
\text { (SD) } \\
\end{array}$ & $\begin{array}{l}\mathrm{t} \\
\text { meaning } \\
(t \leq \\
0,095)\end{array}$ \\
\hline \multirow{2}{*}{$\begin{array}{l}\text { I know how to collaborate effectively } \\
\text { with pedagogues and administration }\end{array}$} & Male & 23 & 2,26 & 0,864 & \multirow[t]{2}{*}{0,518} \\
\hline & Female & 153 & 2,14 & 0,851 & \\
\hline \multirow{2}{*}{$\begin{array}{l}\text { I collect and use professional } \\
\text { information, I deepen my knowledge } \\
\text { about positive collaboration }\end{array}$} & Male & 23 & 2,35 & 0,885 & \multirow{2}{*}{0,317} \\
\hline & Female & 153 & 2,23 & 0,885 & \\
\hline \multirow{2}{*}{$\begin{array}{l}\text { I'm participate in different events } \\
\text { organized by administration and } \\
\text { pedagogues actively }\end{array}$} & Male & 23 & 2,35 & 0,885 & \multirow{2}{*}{0,548} \\
\hline & Female & 153 & 2,23 & 0,885 & \\
\hline \multirow{2}{*}{$\begin{array}{l}\text { I feel that my decisions and opinion } \\
\text { are meaningful for community of } \\
\text { the institution }\end{array}$} & Male & 23 & 2,61 & 0,499 & \multirow[b]{2}{*}{$\mathbf{0 , 0 6 1}$} \\
\hline & Female & 153 & 2,38 & 0,707 & \\
\hline
\end{tabular}


SOCIETY. INTEGRATION. EDUCATION. Volume III

\begin{tabular}{|c|c|c|c|c|c|}
\hline \multirow{2}{*}{$\begin{array}{l}\text { I'm able to plan and organize } \\
\text { activities }\end{array}$} & Male & 23 & 2,52 & 0,511 & \multirow{2}{*}{0,019} \\
\hline & Female & 153 & 2,23 & 0,664 & \\
\hline \multirow{2}{*}{$\begin{array}{l}\text { I' } \mathrm{m} \text { able to decree decisions } \\
\text { concerning organization of education } \\
\text { processes in the school }\end{array}$} & Male & 23 & 2,35 & 0,885 & \multirow{2}{*}{0,548} \\
\hline & Female & 153 & 2,23 & 0,885 & \\
\hline \multirow{2}{*}{$\begin{array}{l}\text { I'm go-ahead and independent } \\
\text { collaborating with participants of } \\
\text { education process }\end{array}$} & Male & 23 & 2,74 & 0,449 & \multirow[b]{2}{*}{0,004} \\
\hline & Female & 153 & 2,41 & 0,711 & \\
\hline \multirow{2}{*}{$\begin{array}{l}\text { I'm able to solve conflicts and } \\
\text { problematic situations }\end{array}$} & Male & 23 & 1,91 & 0,848 & \multirow[t]{2}{*}{0,856} \\
\hline & Female & 153 & 1,95 & 0,857 & \\
\hline \multirow{2}{*}{$\begin{array}{l}\text { I have abilities of communication } \\
\text { and management of information } \\
\text { (collection, saving, analysis) }\end{array}$} & Male & 23 & 2,87 & 0,344 & \multirow[b]{2}{*}{0,002} \\
\hline & Female & 153 & 2,57 & 0,714 & \\
\hline \multirow{2}{*}{$\begin{array}{l}\text { I can initiate school community's } \\
\text { collaboration by myself. }\end{array}$} & Male & 23 & 2,30 & 0,876 & \multirow[t]{2}{*}{0,985} \\
\hline & Female & 153 & 2,30 & 0,904 & \\
\hline \multirow{2}{*}{$\begin{array}{l}\text { I have personal features (activity, } \\
\text { responsibility, ext.) that stimulates } \\
\text { collaboration of participants of } \\
\text { education process. }\end{array}$} & Male & 23 & 2,87 & 0,344 & \multirow[b]{2}{*}{0,002} \\
\hline & Female & 153 & 2,58 & 0,714 & \\
\hline \multirow{2}{*}{$\begin{array}{l}\text { I'm able to share own experience with } \\
\text { others. }\end{array}$} & Male & 23 & 2,48 & 0,898 & \multirow[t]{2}{*}{0,250} \\
\hline & Female & 153 & 2,23 & 0,977 & \\
\hline \multirow{2}{*}{$\begin{array}{l}\text { I allot suggestions concerning } \\
\text { development of effective } \\
\text { collaboration }\end{array}$} & Male & 23 & 2,48 & 0,898 & \multirow[b]{2}{*}{0,250} \\
\hline & Female & 153 & 2,23 & 0,977 & \\
\hline
\end{tabular}

Pedagogues and family members collaborate solving various questions associated with social support. In this stage of research abilities and attempts of respondents to collaborate effectively in order to insure quality of social education process was analyzed.

Statistically significant differences of averages were revealed in the statements: I feel that my decisions and opinion are meaningful for community of the institution $(t \leq 0,06)$, I' $\mathrm{m}$ able to plan and organize activities $(t \leq 0,019)$, I'm go-ahead and independent collaborating with Participants of educational process $(t \leq 0,004)$, I have abilities of communication and management of information (collection, saving, analysis) $(t \leq 0,002)$.

Differences of averages in different groups of statements were major in the choices of men - pedagogue's group. Significant differences according to the age and work experience of respondents were not found as well as analyzing other statements, revealing pedagogue's abilities and attempts to collaborate with other participants of education process.

We can talk about tendencies that were revealed analyzing other choices. Pedagogues states that they are able to share own experience, to allot suggestions concerning development of effective collaboration, they collecting 
and using professional information and deepen their knowledge about positive collaboration,pedagogues know how to collaborate with pedagogues and administration effectively, respondents indicated that they participate in different events organized by administration and pedagogues actively.

Collaboration areas between participants of education process that were revealed the research are mentioned in the main documents that define activity of social educator as well:Social Educator Training Requirements (2001), Official Instructions of Social Educator (2001), Regulation of Social Support Render (2011).

Opinion of family members about necessity of collaboration, development of its successful and unsuccessful forms was analyzed as well. Applying semistructuralized interview gained empiric data was processed using method of content analysis according to foreseen diagnostic areas.Family members were asked to express their opinion on positive and negative collaboration, what collaboration forms are successful and which are not in the context of social education process. The analysis of empiric data let to single out semantic categories (see Table 2).

Table 2. Successful forms of collaboration (parent's opinion, $\mathbf{N}=15$ )

\begin{tabular}{|l|l|l|}
\hline \multicolumn{1}{|c|}{ Category } & \multicolumn{1}{|c|}{ Illustrating statements (example) } & $\begin{array}{l}\text { Number of } \\
\text { Statements }\end{array}$ \\
\hline Conversation & $\begin{array}{l}\text { Direct talk with class master; with subject teachers; } \\
\text { warm and sincere conversation; up my mind } \\
\text { arrangement of parent days, individual conversations } \\
\text { with subject teachers and school events with parent's } \\
\text { participation; dialogs supporting to confide and to } \\
\text { express heart sores; }\end{array}$ & \\
\hline $\begin{array}{l}\text { Sharing of } \\
\text { information }\end{array}$ & $\begin{array}{l}\text { Detail information; communication, sharing of } \\
\text { information (example, TAMO, leaflets, non-formal } \\
\text { sessions, developing collaboration, exp. It could be } \\
\text { posters on different subjects, correspondence.) }\end{array}$ & \\
\hline Discussions & $\begin{array}{l}\text { discussion; round table discussions, group discussions } \\
\text { Common activities, events and ext.; trips and excursions; }\end{array}$ & 5 \\
\hline afternoon events with participant of patents; activities \\
for pedagogues and children, other common events; \\
when parents are involved into school events they meet \\
each other, get acquainted with learning environment, \\
teachers; meetings; consultations; various contacts with \\
people.
\end{tabular}


Research data reveal that successful forms of collaboration according to the informant's opinion are: conversations (8), sharing of information (6), discussions (5), common activities (5), and objective assessment of pupils (3). Parents want to talk with pedagogues, to get information (during conversations, correspondents, TAMO) about their children, their achievements, events taking place in the institution. Family members mentioned sincere and warm communication, conversations that support opportunity to express their sore feelings and at the same time to feel close members of institutional community. Parents wish and are ready for active collaboration forms: to participate in group discussions, to participate in the round table discussions. It means that participants of educational process are active, mature, and open to challenges to solve problems of pupil's social education. Common ideas were mentioned in the scientific studies of Kontautienè (2010) \& Merfeldaitè (2009). As Ališauskienė \& Miltenienè (2003) mentioned effective collaboration of participants of education process and creation of positive educational environment show their maturity that let to fee everyone equal and meaningful. It could be carried out presumptions that these findings create positive conditions for the organization of processes of social education.

Analysis of the research data shows that parents envisage other successful forms of collaboration as well. It is common activities of the community (common events, trips, excursions, meetings, discussions). During such activities children, parents and pedagogues could learn more about each other, they could know each other more objectively, and talk about problems and find ways of its solutions. Being involved into activities of school community family members could feel themselves not only as creators of general school wellness or "firemen's" of occurred problems. Parents become equal and full-value members of social education processes in school as well.

It was foreseen to reveal factors that conditions unsuccessful collaboration between participants of education process (see Table 3 ).

Analysis of research data indicate that parents pointed out five categories describing unsuccessful forms of collaboration. It is lack of competencies (8), public talks (7), rigor collaboration (7) and personal characteristics that common for non-mature pedagogue's personality (7). Incoherence, insufficient knowledge about pupils, bias solving children problems - these personal characteristics of pedagogues were mentioned by parents as well. According to the informants opinion pedagogues are not motivated for collaboration always, they don't want to hear negative information concerning pupil's or families' bothers, and usually the limits their collaboration informing parents about occurred problems without attempts to solve problematic situations.

Informants are not satisfied with pedagogue's behavior when children problems are discussed publicly during class meetings, by phone calls or even stopped in the street, they feel depressed when they hear eminently expressed 
demand for collaboration; peremptory strain invitation to visit school due to the child problems which sometimes are not serious.

Table 3. Unsuccessful forms of collaboration (parent's opinion)

\begin{tabular}{|c|c|c|}
\hline Category & Illustrating statements (examples) & $\begin{array}{l}\text { Number of } \\
\text { statements }\end{array}$ \\
\hline $\begin{array}{l}\text { Lack of } \\
\text { competencies }\end{array}$ & $\begin{array}{l}\text { Teacher's lack of sequence working with pupils; tasks } \\
\text { that are given without discussions in classroom, they } \\
\text { are desultory... When teachers don't know pupils well; } \\
\text { there is no collaboration when I didn't get answer; } \\
\text { There is no wish to collaborate; reluctance to hear } \\
\text { negative information; lack of competencies; the most } \\
\text { unsuccessful forms of collaboration when parents are } \\
\text { simply informed about problems without suggestion } \\
\text { how to solve them; unfairness when one side has right } \\
\text { to talk; }\end{array}$ & 8 \\
\hline Public talks & $\begin{array}{l}\text { Publicity, phone calls, to stop person in the } \\
\text { street,temporal and public communication, public } \\
\text { information during parent meetings, public talks in the } \\
\text { stores, conversations about children in the streets; }\end{array}$ & 7 \\
\hline $\begin{array}{l}\text { Rigor } \\
\text { collaboration }\end{array}$ & $\begin{array}{l}\text { Eminently expressed demand for collaboration; when } \\
\text { some problems in the school appear invited parents not } \\
\text { be frightened; peremptory straininviting parents to } \\
\text { visit school; prominent and strict request to come to } \\
\text { the school due to the child problems which sometimes } \\
\text { are not serious; }\end{array}$ & 7 \\
\hline $\begin{array}{l}\text { Personal } \\
\text { characteristics }\end{array}$ & $\begin{array}{l}\text { Lack of communicability, laziness, insincerity, spite, } \\
\text { envy, there is no confidence in each other, tension and } \\
\text { fear to insulted by othersonly, intolerance, } \\
\text { vindictiveness, incoherence, prominence of own } \\
\text { personality. }\end{array}$ & 7 \\
\hline $\begin{array}{l}\text { Other forms of } \\
\text { unsuccessful } \\
\text { collaboration }\end{array}$ & Questionnaires; researches; correspondence. & 5 \\
\hline
\end{tabular}

The results of the research reveal that parents envisage features of nonmature personality of pedagogues as specialists. Family members mentioned lack of professional competencies, pedagogues insincere, virulence, jealousy, intolerant. These personal characteristics limits person's maturing process and at the same it creates barriers for person professional mastership (Rogers, 2005; Maslou, 2006).

\section{Conclusions}

1. Communities of education systems are not able to solve complex social and educational problems in the conditions of globalization and social integration. In order to satisfy pupil's needs and to insure their social 
wellness, it is necessary to mass collaboration of participants of education process organizing effective social education. These processes are foreseen in the documents regulating education system of Republic of Lithuania including social education as well.

2. Data of quantitative research reveal abilities of pedagogue's to organize institutional social education. Statistically significant differences of averages show that pedagogues understand importance of their decisions in education communities $(\mathrm{t} \leq 0,061)$, respondents are able to plan and organize social education $(\mathrm{t} \leq 0,019)$, and they are initiative and independent collaborating with participants in the education process $(t \leq 0,004)$. Results of the qualitative research show that for successful forms of collaboration informants indicated discussions, sharing of information, common activities and objective evaluation of pupil's academic achievements.

3. Family members are open for such collaboration forms as round table discussions, and it show's their activity, readiness for changes. As negative forms of collaboration lack of professional competences of pedagogues, public discussions about pupil's social problems and strict communication were mentioned. These personal characteristics limits person's maturing process and at the same it creates barriers for person professional mastership.

\section{References}

Alifanovienė, D., Vaitkevičienė \& A., Musvicienė, Ž., (2014). Analysis of Social Educators' and Parents' Cooperation Possibilities: Promoting and Hindering Factors. Social Welfare: Interdisciplinary Approach. 4 (1), 8-17.

Ališauskienè, S.\& Miltenienè, L.(2003). Tèvu, specialistu ir specialiuju poreikiu turinčiu vaiku bendradarbiavimo pletote ugdymo institucijose (ankstyvosios reabilitacijos tarnybose ir bendrojo lavinimo mokyklose): tyrimo ataskaita. Šiauliai: ŠU. Retriewed from: http://www.smm.lt/svietimo_bukle/docs/ataskaita_smm_03.doc(2014.02.11).

Aramavičiūtè, V. (2009). Šiuolaikinio žmogaus socializacija Juozo Vaitkevičiaus socialinèje pedagogikoje. Acta pedagogika Vilensija, 22, p.163-173.

Bitinas, B. (2000). Ugdymo filosofija. Vilnius: Enciklopedija.

Dabartinès lietuviu kalbos žodynas (2006). St. Keinys (ed.), Bilkis L., Paulauskas J. \& Vitkauskas V. (6-as leid.)- Vilnius: Lietuvių kalbos institutas.

Indrašienė V., Kvieskienè G. \& Merfeldaitè O. (2007). Tarpdalykinès socialinès-pedagoginès pagalbos komandos veiklos modelis, sprendžiant vaikų socialinès atskirties problemas. Tiltai. Nr. 4 (41) KU.

Lietuvos pažangos strategija „Lietuva 2030“. Patvirtinta Lietuvos Respublikos Seimo 2012 m. gegužès $15 \mathrm{~d}$. пиtarimu Nr. XI-2015. Retriewed from: http://www3.lrs.lt/pls/inter3/dokpaieska.showdoc_1?p_id=425517\&p_query $=\& p \_t r 2=2$ (2014.05.05).

Lietuvos Respublikos švietimo istatymo pakeitimo istatymas. $2011 \mathrm{~m}$. kovo 17 d. Nr. XI1281.Valstybès žinios, 2003-06-28, Nr.63-2853.

Kontautiene, R. (2010). Bendradarbiavimo sistema ir jos valdymas mokykloje. Klaipeda: KU leidykla. 
Leliūgienè, I.\& Terechovienè, R.(2011). Socialinio pedagogo kompetencijų raiška mokykloje. Socialinis darbas. 10(2), 193-204.

Maslow, A. (2006). Motyvacija ir asmenybe. Vilnius: Apostrofa.

Merfeldaitès, O. (2009). Tèvų ir mokyklos bendradarbiavimo stiprinimas sprendžiant vaikų socializacijos problemas. Socialinis ugdymas. T. 19. Vilnius,2009,p. 93-103

Rogers, C. R. (2005). Apie tapima asmeniu. Vilnius: Via Recta.

Socialinio pedagogo pareigine instrukcija. LR Švietimo ir mokslo ministro 20011214 isakymas Nr. 1667. Retriewed from: http://www.smm.lt/teisine_baze/docs/ isakymai/01_12_1667.htm (2014.05.05).

Socialinès pedagoginès pagalbos teikimo tvarkos aprašas. Patvirtinta Lietuvos Respublikos švietimo ir mokslo ministro $2004 \mathrm{~m}$. birželio 15 d. isakymu Nr. ISAK-941. (Lietuvos Respublikos švietimo ir mokslo ministro2011 m. liepos $21 \mathrm{~d}$. isakymo $\mathrm{Nr}$. V-1393 redakcija). Retriewed from: http://www3.lrs.lt/pls/inter3/dokpaieska.showdoc_1? p_id $=404471 \& p \_q u e r y=\& p \_t r 2=(2014.05 .05)$.

Vaiko geroves 2013-2018 metu programa. Patvirtinta Lietuvos Respublikos Socialines apsaugos ir darbo ministro $2012 \mathrm{~m}$. gruodžio $3 \mathrm{~d}$. isakymu Nr. A1-547. Retriewed from: http:// www3. 1rs.lt/pls/inter3/ dokpaieska. showdoc_ 1?p_ id= 438640\&p_query $=\& p_{-}$tr2 $=2(2014.05 .05)$.

Vaitkevičius, J. (1995). Socialinès pedagogikos pagrindai. Vilnius: Egalda.

Valstybiné švietimo 2013-2022 metu strategija. Patvirtinta Lietuvos Respublikos Seimo 2013 m. gruodžio $23 \mathrm{~d}$. nutarimu Nr. XII-745. Retriewed from: https://www.etar.lt/portal/forms/legalAct.html?documentId=b1fb6cc089d911e397b5c02d3197f382 (2014.05.05). 